\title{
FGF8 wt Allele
}

National Cancer Institute

\section{Source}

National Cancer Institute. FGF8 wt Allele. NCI Thesaurus. Code C51503.

Human FGF8 wild-type allele is located within 10q24 and is approximately $6 \mathrm{~kb}$ in length.

This allele, which encodes fibroblast growth factor 8 protein, plays a role in embryonic epithelial regulation and angiogenesis. 